\title{
COUNTERING SUBTRACTIVE BILINGUALISM WITH ADDITIVE BILINGUALISM IN THE ALBANIAN LANGUAGE
}

\section{Dr. Sc. Diedon DORAMBARI id}

AAB College, Faculty of Psychology,d_diedon@hotmail.com

\author{
Article history: \\ Submission 12 November 2020 \\ Revision 29 November 2020 \\ Accepted 30 January 2021 \\ Available online 30 April 2021
}

\section{Keywords:}

Subtractive Bilingualism

Additive Bilingualism,

Ethnolinguistic Vitality,

Ethnic Identity Preservation.

DOI:

https://doi.org/10.32936/pssj.v5i1.198

\begin{abstract}
A b s t r a c t
The English language is the lingua franca of education, trade, and employment. However, with such a global influence, the English language sometimes interferes with the native languages via subtractive bilingualism. The aim of this essay is to explain the negative effects of subtractive bilingualism on a global scale in general, elaborate on its negative effects on the Albanian language in particular, and propose solutions to the problem.

To achieve such an aim, research related to the macroscopic model of determinants of additive and subtractive bilingualism (MMDASB) was consulted. Based on the research findings, I conclude that the school milieu should lead by example in using additive bilingualism to counter subtractive bilingualism. In doing so, the school milieu would counter subtractive bilingualism on the sociological, socio-psychological, and psychological levels as predicted in the MMDASB (Landry \& Allard, 1993) model. Following the conclusion, concrete proposals for promoting additive bilingualism by the higher education in the school milieu are recommended.
\end{abstract}

\section{Introduction}

The baby cannot eat a whole fried chicken; neither can eat a whole hot chilly

And you want her to start running without learning how to walk? Well you could try giving her an Arabian pacifier, or you could try a French pacifier

She will always ask for the mothers ' milk, fool!

\section{Ali Podrimja, The Mothers' Milk}

The ethnolinguistic vitality (EV) of the ethnic identity is "that which makes a group likely to behave as a distinctive and active collective entity in intergroup situations" (Giles, Bourhis \& Taylor, 1977, as cited in Landry \& Allard, 1993, p. 7). However, today the ethnic identity is threatened (Pavlenko 2003) by EV reduction on a global scale due to Anglicization (King, 2017) delivered mostly via the internet (Vincze \& Joyce, 2017). Thus, the primary purpose of this essay is to increase the awareness of such an influence on the Albanian language. The secondary purpose is to offer a solution on how to preserve the ethnic identity by revitalizing the EV based on the macroscopic model of determinants of additive and subtractive bilingualism (MMDASB, Landry \& Allard, 1993).

\section{Literature Review}

The MMDASB proposes that the EV of an ethnic identity depends on the capital of demographic, political, economic, and cultural fields (Landry \& Allard, 1993). According to the model, low capital in any field will limit access, lessen contacts and deprive one from communicating in their ethnolinguistic language (L1) because they will be forced to communicate in the second (L2) language. For example, if an Albanian during the former Yugoslavian era were to go shopping, work, watch TV, listen to music, seek help from the government (health, welfare, crime related problems, etc), then they would have to communicate in the Yugoslavian Serbo-Croatian (L2) language mostly (rather than in their Albanian L1 language).

With such little capital in all or most of the fields mentioned in MMDASB (i.e., no institutional completeness), the Albanian EV was less powerful to organize and maintain their members away from the larger influence of the former Yugoslavia. Except in rare circumstances (Ahmed, 2016; Wright, Taylor, \& McArthur, 
2000), it is generally believed that such ethno-linguistic groups with low EV either assimilate or cease to exist as a distinct collective entity due to the effect of subtractive bilingualism (Landry \& Allard, 1993).

\subsection{Subtractive Bilingualism}

Subtractive bilingualism means doing away the L1 (e.g., Albanian) words in favor of L2 (e.g., Serbo-Croatian) words (Lambert, 1975). As such, the Albanian words would be replaced with the Serbo-Croatian ones via subtractive bilingualism during the former Yugoslavian era. The subtractive replacement of words within the sentence then lead to the "Albo-Serbo-CroatianCreole" language made of both L1 and L2 words that were less decipherable to either. For example, Albanians in the former Yugoslavia would use words like "Shkova me e marrë liçna kartën n'SUP [emphasis added]," which is a sentence made of the Serbo-Croatian word "liçna karta" (i.e., ID card) that replaced the Albanian word "letërnjoftim" with subtractive bilingualism.

It is mentioned in the Landry and Allard (1993) article that subtractive bilingualism is linked with low IQ and poor academic performance. The authors found that people with low EV both rate themselves and are more academically fluent in the L2 rather than in their L1 language. In addition, they found that the people with low EV that succumb to subtractive bilingualism wish the least to identify themselves with their L1 ethnic group and the most with the L2 ethnic group. Such intrusion of the L2 language in the members of the L1 cultural identity could raise unequal rights issues, power relations, ethnicism, racism, linguicism (Landry \& Allard, 1993), and fears of becoming an extinct identity (Wright, Taylor \& Macarthur, 2000), which may be one reason behind the 1999 war of liberation (Webber, 2009).

However, although today Dardania ${ }^{1}$ is free (Buxhovi, 2013) and has capital on the EV sustaining fields mentioned in the MMDASB, the subtractive bilingualism (though altered) still lingers. Despite the Albanian capital on most EV maintaining fields, the Albanian media field seems to struggle to keep up with the Anglophonic media delivered via the internet (like Facebook, Tsoumou, 2019), which may influence the Albanian identity (like it influences the Fin and Swede media identity, Vincze \& Joyce, 2017). Since the English language is now the world's lingua franca (King, 2017), then the English (L2) words are now replacing the Albanian (L1) ones in turn and resulting in a genuine "Albo-Anglo-Creole" language, which again is less decipherable by either language. For example, the Albo-AngloCreole language would now consist of sentences like "Shkova me e marrë ID-në n'kuvend komunal [emphasis added]," where now

\footnotetext{
${ }^{1}$ The author calls the country Kosovo as "Dardania"
}

the English word "ID" replaces the Albanian one "letërnjoftim" with subtractive bilingualism.

Instead of trying to increase, all the capital in all the fields mentioned in the MMDASB currently use the Albo-Anglo-Creole (see explanation above) language to a degree, which instead decreases the Albanian EV (and thus identity) via subtractive bilingualism. Despite having a particular word in Albanian, an English word would be used within an Albanian sentence during communication in sociological, socio-psychological, as well as psychological levels. Although after liberation (Webber, 2009), subtractive bilingualism may seem surprising to continue, the phenomenon is occurring at a global scale.

\subsection{Prevalence of Subtractive Bilingualism}

Even though subtractive bilingualism historically "contaminated" the national identity, and even though it is perceived as a known historical threat to the EV (Pavlenko, 2003), there is nevertheless uncertainty how to respond to the increasing Creole like language in various parts of the world. For instance, in the major parts of Europe they are trying to counter the effects of Anglicization, while South Africa and Asia are currently debating the issue. In Malaysia, a policy has been made to drop teaching English altogether, the matter is considered as "controversial" in Indonesia, and Singapore (King, 2017), it is not a visible language in the educational realm in Israel (Yoel, 2020).

Even in big countries like China (whose shear identity may not be perceived as threatened by the Anglo-Mandarin-Creole), the intrusion in their Mandarin language has also caused them to hate and even reject the English language altogether (King, 2017). Thereby, in this paper the possible steps on elevating the Albanian EV and ethnic identity will be now proposed. The issue of additive bilingualism will be considered as an option from various pro and against perspectives.

\section{National Additive Bilingualism}

In the $1920 \mathrm{~s}$ and $30 \mathrm{~s}$, researchers found evidence that posited bilingualism as hindering intelligence. Since then, research taken in Singapore, Switzerland, South Africa, Israel, USA, and Canada found evidence that bilingual children had advantages on cognitive flexibility, creativity, and divergent thought compared to monolingual children. The reason behind the conflicting findings was attributed to participants' values during language acquisition (Lambert, 1975).

If participants added a valued and respected L2 language to their repertoire of languages (including their L1 language) then this was considered as additive bilingualism. If participants added a 
new language (L2) at the price of their native language (L1) due to national educational policies or social pressure, then due to diglossia the primary language was reduced with subtractive bilingualism (Lambert, 1975). Compared to subtractive bilingualism, additive bilingualism has many more benefits.

First, people who are additive bilinguals have higher metalinguistic and metacognitive awareness, working memory, abstract and symbolic representation, problem solving, and attention control. Second, since additive bilinguals need to coordinate two languages every day, then this experience allows them greater practice and efficiency in exercising cognitive control. Third, the previously mentioned higher order cognitive activities were also found in brain imaging studies where there were more gray matter and hippocampal activity, which are in turn linked with greater conflict resolution ability (Ardasheva, Tretter \& Kinny 2012).

Thereby, if the goal is to both preserve the Albanian EV and ethnic identity, as well as increase the cognitive flexibility, creativity, and divergent thinking (especially for students), then additive bilingualism should be promoted. Although such a national approach against subtractive bilingualism was also proposed in the post-Apartheid South African era (Lucket, 1993), the difference in this paper is for the Albanian higher education to lead-by-example. Thus, the counterarguments to additive bilingualism being promoted by example from the higher education shall now be discussed.

\subsection{The Leading Country in Additive Bilingualism}

Since the negative effects of subtractive bilingualism are known to the better developed countries that also perceive their identities as threatened by Anglicization (King, 2017; Pavlenko, 2003), then one solution may be to remain passive. Whenever the other more developed countries find a solution then Albanians could consider adopting the solution to themselves (e.g., various solutions in various countries mentioned in the García, Lin \& May, 2017 article). Basically, the position seems to be to let others deal with the problem first, not the Albanians themselves.

The problem with such a position is that what may be a solution to other countries may not be appropriate to the Albanians. For instance, the solution in Malaysia was to create a policy to stop teaching English altogether (King, 2017), while in Kenya the solution is to teach their native language via English (Mwaniki et $\mathrm{al}, 2017$ ). If such policies were created to reduce the negative effects of subtractive bilingualism by becoming monolingual, then it would be a mistake on several grounds for the Albanians to take a similar path.
First, the historic norm for most of the people in various countries of the world was to be bilingual because monolingualism was considered as a handicap. Second, since to avoid the handicap people should learn to be bilinguals, and English is currently the lingua franca, then there is currently hardly any other language that could be as useful as the English language (King, 2017). Third, since currently the Anglophonic countries are some of the best allies to the Albanian people, then losing the skill to communicate in English might needlessly handicap communications with the latter, which could work against national and political interests.

Thereby, since other countries' solutions to subtractive bilingualism may not necessarily help by default, then it should be up to the Albanians themselves to find a solution that is appropriate to their national interests instead. One such solution offered here is to use additive bilingualism (rather than monolingualism) to counter subtractive bilingualism. But who should take the leading role of promoting the additive bilingualism amongst Albanians?

In other words, although the passive position mentioned above may not be appropriate between the countries, it may nevertheless be appropriate within the country. The position more precisely seems to be: Let someone else within the country deal with the Albo-Anglo-Creole problem, not the higher education.

According to the MMDASP, when one field lacks enough capital, then such a lack of capital in the field can be compensated by power and resources from the other fields. For instance, if the higher in capital L2 language intrudes with the low capital L1 language' families and schools, then those families and school key members must compensate for the overload of contacts that the L1 member must have with the L2 members by securing additive bilingualism. On the other hand, if the L1 is high in capital, then the schools should provide the L1 members with an opportunity to learn the L2 language and thus promote additive bilingualism just as well (Landry \& Allard, 1993).

Thus, the school milieu takes the lead in countering subtractive bilingualism and preserving the EV and ethnic identity of a nation no matter if there is greater capital in L1 or L2. Thereby, far from primary, secondary, and the higher education using the AlboAnglo-Creole language (as currently seems to be the case) the school milieu should lead the way by example of communicating with their students with additive bilingualism instead. More concretely, the staff in the higher education should pave the way of leading the other fields in preserving the Albanian EV, ethnic identity, as well as cognitively and academically benefiting their students with additive bilingualism. 


\subsection{The Stagnated Vocabulary}

A counterargument in taking the leadership role with additive bilingualism in higher education may be beliefs that the vocabularies stagnate. The position may be that the English language is more advanced than the Albanian one by default and nothing can be done to change that. As if, a long time ago, somewhere, someone wrote the language vocabularies, and the same vocabulary has been in use to represent whatever new concept may have been developed since then (even the word "internet"). Neither a new word came in to represent a new meaning, nor did an old word drop since then due to such stagnation.

Thus, some more fortunate languages (such as the English one) happened to have more words to cover more meanings both quantitatively and qualitatively. Other less fortunate languages (such as the Albanian one) did not have that good fate and thus the stagnation maintained an advantage for the former by default. Further, due to the above mentioned stagnation, the gap between the two languages can never be reached, which might account for the Albanian diglossia towards the Albanian language in favor of the English one.

Due to such vocabulary related diglossia, the vernacular Albanian language is used mostly in the "lower domain" of family, sport, religion, and agriculture. Ironically, despite the damage from subtractive bilingualism, the privilege of using the Albo-AngloCreole is mostly reserved for the "higher domain" such as in education, politics, and law (just like in post-Apartheid South Africa, Lucket, 1993). However, diglossia could occur in different circumstances as well.

For instance, the diglossic situations occurred when the francophone people tried to establish a higher stricter French standard language compared to their vernacular one in Canada (Heller, 1996). Similarly, the bilingual educators disparaged the African-American vernacular English in the USA in favor of the standard one (Choi, 2017). Lastly, during the post- apartheid colonial phase in South Africa, English was used in the higher domain while the local language in the lower one (Lucket, 1993). If it is a matter of enriching the vocabulary, then there may be benefits in the realization that the English vocabulary is constantly maintained. New words are constantly created to represent a new meaning, while less used words become obsolete and are dropped out from the vocabulary (Sternberg, 2009). New words are created via affixation, back formation, blending, clipping, compounding, and conversion (Nordquist, 2019). All new words initially start with neologism, and eventually (depending on usage) become mainstream words that are finally added to the vocabulary by the dictionary editors (MerriamWebster, 2020).

Thereby, if new words lack in the Albanian vocabulary, then rather than succumb to diglossia, subtractive bilingualism, and lower the EV with the Albo-Anglo-Creole sentences, the new words should be created to represent the never ending new meanings. Not doing so might indeed result in a unilateral "vocabulary stagnation," but it may also result in less EV influence to hold the Albanian members together, counterassimilation influences, or worse, result in the undecipherable by either mainstream Albo-Anglo-Creole language. However, with this path the consequences of low EV (and all that it may entail) may fall upon the Albanian decision, and not their "fate."

\subsection{The Albo-Anglo-Creole Shortcut}

Another position against additive bilingualism could be circumlocutory beliefs. More precisely, the position could be of teachers hesitating to teach the new concepts in the Albanian (L1) language since both the origin of the concept and its future dissemination is mostly in the lingua franca English (L2) language. Basically, the position seems to be: Why not introduce the new concept in the Albo-Anglo-Creole word as a shortcut since the students will use the English properties of the language to communicate the meaning easier in the lingua franca language anyway? There are several pitfalls with the position that undermines the negative effects of subtractive bilingualism, while it posits itself as if doing a service to the Albanian EV and language acquisition.

First, when introducing the new concept in the L1 (e.g., Albanian) language, the teachers would provide a genuine insight into the concept, which then benefits the students in a number of ways, such as: (a) The insight in L1 could scaffold the ability of students to better understand the concept in L2, (b) when the new concept is introduced in L1 it would both better build on the students' prior knowledge, ethnolinguistic identity, as well as it could better connect with their lives outside of school (which are largely in the L1 language), (c) the instruction of the concept in L1 serves the EV by affirming the students' academic, linguistic, and cultural identity by showcasing the literacy achievement in the L1 and the academic language, and (d) their L1 and L2 language vocabulary is extended to cover other meanings as they go through the curriculum via transfer of competencies (King, 2017).

Second, by building on the benefits mentioned above, the introduced new concept in the Albanian (L1) language would help the students learn the English (L2) language better. The way it works is that the cognitive and academic competencies achieved in the enriched L1 vocabulary would then transfer to the 
L2 language, and vice versa (Ardasheva, Tretter \& Kinny, 2012; MacSwan et al, 2017; Romero \& Manjares, 2017). More precisely, the conceptual and linguistic elements, the morphological and phonological awareness, the metacognitive and metalinguistic strategies, as well as the pragmatic aspects of using the L1 language (in this case, Albanian) would transfer into the L2 (i.e., English) language (Cummins, 2017). Thereby, far from helping the students with their English (L2) language, by introducing the new concepts directly in the Albo-Anglo-Creole words, there is no service to either the Albanian EV, English language acquisition, or making communications any easier with the Anglophonic people.

\section{Responding to Subtractive Bilingualism: Precise Proposals}

The decision whether to respond to subtractive bilingualism may rest on a nationwide measurement of the Albanian EV. If the scores are low, then the language maintaining agents should develop future projects to revitalize the EV (Landweer, 2016). Rather than possibly resort to revitalizing the indigenous Albanian language in the future (like currently with the Inuit identity, McIvor \& McCarty, 2017), I propose that the higher education should take the initiative now (to prevent such a possible outcome in the future) by leading with example and promoting additive bilingualism with the following measures.

\subsection{Albanian Vocabulary Update}

The vocabulary in the Albanian (L1) language (especially academic) should cover more meanings much like the English (L2) one. For this to occur, the Albanian vocabulary should always be updated to include the never ending new meanings that the current and the future times may hold.

More precisely, since it is up to the school milieu to lead the way in countering the subtractive bilingualism (Landry \& Allard, 1993), then it is up to the higher education to update the Albanian vocabulary. This could be done by following the set example in the lingua franca English language (Nordquist, 2019; MerriamWebster, 2020). Namely, initially new Albanian words may be offered (i.e., neologism) that would match the English. Later, those new Albanian words could allow the students to transfer the meaning in English (and thus learn the English language better) by placing in the brackets the same meaning in the English word (e.g., Letërnjoftim [Identity Card]).

When all the teachers and professors propose new words for the new meanings in their respective courses, then many competing Albanian words could be generated that may qualify for entering the Albanian dictionary. When the students adopt the new Albanian words during the introduction in class, then the use of such words outside of the school could be tracked in their homework, essays, or even social media. The proposed words in Albanian that are more frequently used from the students (or their contacts) could then gain entry as a new word to the Albanian dictionary. The words in the Albanian dictionary would then be used to teach the new content throughout the curriculum in primary, secondary, and higher education.

\subsection{Albanian-English Translanguaging}

Since demonstrating multilingualism is normal (King, 2017), while subtractive bilingualism is harmful (Landry \& Allard, 1993), and since even the Anglophone countries promote additive bilingualism (where L2 is a non-English language, Dicks \& Genese, 2017; Gandara \& Escamila. 2017) then a follow up question may arise: How can one speak in L2 and not perpetrate subtractive bilingualism? The key issue is the degree that languages are mixed while communicating.

For instance, one approach may be using the monolingual principle where the languages are kept mostly separate. With this principle, a course is either presented in the L2 (e.g., the Berlitz method, Berlitz, 2019) or the L1 language. However, such an approach has lost its credibility because it did not allow much cross-language transfer (Cummins, 2017). Thereby, some boundaries between languages need to soften while still keep away from in-sentence word mixing (i.e., Albo-Anglo-Creole language).

To ensure greater cross-language transfer, and not use the AlboAnglo-Creole language, the translanguaging approach is offered here instead. With translanguaging, rather than lecture the entire course purely in L1 (e.g., in Albanian) or L2 (e.g., English) via the monolinguistic principle, a single class course is separated to parts that will use a language type. For instance, lecturing could be kept in L1, while exercises, homework, or essays could be done in L2 (Cummins, 2017; King, 2017).

There may be many advantages of translanguaging, such as: (a) Promoting a deeper and fuller understanding of the subject matter, (b) help development of the weaker language (e.g., the Albanian dictionary), (c) facilitate cooperation, and (d) integrate fluent speakers with early learners (García \& Lin, 2017).

\subsection{Albanian-English Code-Switching}

Another way to counter subtractive bilingualism, use the L2 English language, and keep away from the Albo-Anglo-Creole is code-switching. With code-switching, rather than use mixed words from two or more languages in one sentence (e.g., AlboAnglo-Creole language), the two languages are kept separate by switching (or oscillating) whole sentences from L1 to L2 (King, 
2017). For instance, during a conversation or a lecture in Albanian, one could switch to communicating the entire upcoming sentence in English, before returning to using the Albanian language again. This may preferably be done by clarifying the earlier made English sentence in Albanian for those that may not understand it (like it is done in the Philippines, Tupas \& Martin 2017).

\section{Conclusions}

Subtractive bilingualism could lower the Albanian EV, IQ, academic performance, language acquisition, and identification of its' members with the Albanian identity. If such negative effects are left unchecked, then subtractive bilingualism could incite ethnicism, racism, and linguicism due to anxieties of becoming an extinct ethnic identity one day. By comparison, additive bilingualism could increase the Albanian EV, language acquisition, cognitive flexibility, creativity, and divergent thinking, which could strengthen both the Albanian ethnic identity and its place among other fellow ethnic identities of the world.

\section{Recommendations}

The concrete proposals that academics in the higher education should take to promote additive bilingualism (and thus disregard subtractive bilingualism) are updating the Albanian dictionary, as well as using translanguaging and code-switching. Despite the negative effects of subtractive bilingualism, and despite the concrete examples to counter it as mentioned in this essay, it nevertheless remains to be seen whether the Albanian EV continues to be lowered by using foreign "pacifiers," or will it increase by using their "mothers' milk."

\section{References}

1. Ahmed, M. (2016). Ethnicity, identity and group vitality: A study of Burushos of Srinagar. Journal of Ethnic and Cultural Studies, Vol. 3, No. 1 p. 1-10. https://dx.doi.org/10.29333/ejecs/51

2. Ardasheva, Y. Tretter, T. R. and Kinny, M. (2012). English language learners and academic achievement: Revisiting the threshold hypothesis. Language Learning, Vol. 3, No. 62 p. $769-812$. https://doi.org/10.1111/j.1467-9922.2011.00652.x

3. Berlitz. (2019). The Berlitz method. Accessed on 12/12/2020, Available at: https://www.berlitz.com/ende/about/berlitz-method

4. Buxhovi, J. (2013). Kosova: Dardania në kohë të lashtë dhe mesjetë, Perandoria Osmane, nga okupimi në protektoratin ndërkombëtarë [Kosova: Dardania in ancient and medieval times, the Ottoman empire, from occupation to international protectorate]. Texas: Jalifat
Publishing. Available at:

http://www.jalifatpublishing.com/books-by-jusufbuxhovi

5. Choi, T. H. (2017). Identity, transnationalism, and bilingual education. in O. García., A. M. Y. Lin., and S. May (Eds.), Bilingual and multilingual education: Vol. 10. Encyclopedia of Language and Education (3rd ed., p. 175 - 189). Springer. https://dx.doi.org/10.1007/978-3319-02258-1 7

6. Cummins, J. (2017). Teaching for transfer in multilingual school contexts. in O. García., A. M. Y. Lin., and S. May (Eds.), Bilingual and multilingual education: Vol. 10. Encyclopedia of Language and Education (3rd ed., p. 103 - 115). Springer. https://dx.doi.org/10.1007/978-3319-02258-1_8

7. Dicks, J. and Genesee, F. (2017). Bilingual education in Canada. in O. García., A. M. Y. Lin., and S. May (Eds.), Bilingual and multilingual education: Vol. 10. Encyclopedia of Language and Education (3rd ed., p. 453-467). Springer. https://dx.doi.org/10.1007/978-3319-02258-1 32

8. Heller, M. (1996). Legitimate language in a multilingual school. Linguistics and Education, Vol 8, No. 2 p. 139157. https://doi.org/10.1016/S0898-5898(96)90011-X

9. Cambridge Assessment English. (2017). The impact of multilingualism on global education and language learning. Cambridge. Available at: https://assets.cambridgeenglish.org/research/perspectives -multilingualism.

10. Lambert, W. (1975). Culture and language as factors in learning and education. in A. Wolfgang (Ed). Education of immigrant students. Toronto: Ontario Institute for Studies in Education. Available at: https://files.eric.ed.gov/fulltext/ED096820.pdf

11. Landry, R. and Allard, R. (1993). Beyond socially naive bilingual education: The effects of schooling and ethnolinguistic vitality of the community on additive and subtractive bilingualism. Annual Conference Journal, pg 1-30. Available at: https://files.eric.ed.gov/fulltext/ED360866.pdf

12. Landweer, M. (2016). Indicators of Ethnolinguistic Vitality Review and Score Sheet. GIA Lens, Vol 10 No. 1, 1-14. Available at: https://www.diu.edu/documents/gialens/Vol101/Landweer-Ethnolinguistic-Vitality.pdf

13. Lucket, K. (1993). National additive bilingualism. South African Linguistics and Applied Language Studies. p. 39-60. https://doi.org/10.1080/10189203.1993.9724614

14. MacSwan, J. Thompson, M. S. Rolstad, K. McAlister, K. and Lobo, G. (2017). Three theories of the effects of 
language education programs: An empirical evaluation of bilingual and English-only policies. Annual Review of

Applied Linguistics, Vol 37 p. 218-240. https://doi.org/10.1017/S0267190517000137

15. Merriam-Webster Dictionary (n.d.). How does a word get into a Merriam-Webster dictionary?. Available at: https://www.merriam-webster.com/help/faq-words-intodictionary

16. McIvor, O. and McCarty, T. L. (2017). Indigenous bilingual revitalization-immersion education in Canada and the USA. in O. García., A. M. Y. Lin., and S. May (Eds.), Bilingual and multilingual education: Vol. 10. Encyclopedia of Language and Education (3rd ed., p. 421-438). Springer. https://doi.org/10.1007/978-3-31902258-1 34

17. Mwaniki, M., Arias, M. B. and Wiley, T. G. (2017). Bilingual education policy. in O. García., A. M. Y. Lin., and S. May (Eds.), Bilingual and multilingual education: Vol. 10. Encyclopedia of Language and Education (3rd ed., p. 35-49). Springer. https://doi.org/10.1007/978-3319-02324-3 3-2

18. Nordquist, R (2019). How are new words created: Six types of word-formation in English. Thoughtco, Accessed on 12/12/2020 Available at: https://www.thoughtco.com/where-do-new-words-comefrom-1692700

19. García, O. and Lin, A. M. Y (2017). Translanguaging in bilingual education. in O. García., A. M. Y. Lin., and S. May (Eds.), Bilingual and multilingual education: Vol.

10. Encyclopedia of Language and Education (3rd ed., p. 117-130). Springer. https://doi.org/10.1007/978-3-31902324-3_1-1

20. Gándara, P. and Escamilla, K. (2017). Bilingual education in the United States. in O. García., A. M. Y. Lin., and S. May (Eds.), Bilingual and multilingual education: Vol. 10. Encyclopedia of Language and Education (3rd ed., p. 439-452). Springer. https://doi.org/10.1007/978-3-319-02324-3 33-1

21. Pavlenko, A. (2003). Language of the enemy': Foreign language education and national identity. International Journal of Bilingual Education and Bilingualism, Vol 6, No. 5 p. 313-331. https://doi.org/10.1080/13670050308667789

22. Sternberg, R. (2009). Cognitive psychology. Ohio, Cengage Learning, 5th Edition.

23. Tsoumou, J. M. (2019). English as an international language: English/French language alternation in politically motivated CMC in Congo-Brazzaville. Journal of English as an International Language, Vol 14, No 2 p.
94-117. Available at:

https://files.eric.ed.gov/fulltext/EJ1244207.pdf

24. Tupas, R. and Martin, I. P. (2017). Bilingual and mother tongue-based multilingual education in Philippines. in $\mathrm{O}$. García., A. M. Y. Lin., and S. May (Eds.), Bilingual and multilingual education: Vol. 10. Encyclopedia of Language and Education (3rd ed., p. 247-258). Springer. https://doi.org/10.1007/978-3-319-02324-3 181

25. Romero, Y. and Manjarres, M. P. (2017). How does the first language have an influence on language learning? A case study in an English ESL classroom. English Language Teaching, Vol 10, No 7 p. 123 - 139. Available at: https://files.eric.ed.gov/fulltext/EJ1144398.pdf

26. Vincze, L. and Joyce, N. (2017). Online contact, face-toface contact, and multilingualism: Young Swedishspeaking Finns develop trilingual identities. Communication Studies, Vol 69, No 1 p. 85-102. https://doi.org/10.1080/10510974.2017.1413410

27. Vincze, L., and Henning-Lindblom, A. (2016). Swedish, Finnish and bilingual? Multiple ethnolinguistic identities in relation to ethnolinguistic vitality in Finland. International Journal of Bilingualism, Vol 20, No 4 p. 488-498. https://doi.org/10.1177/1367006915572169

28. Webber, M. (2009). The Kosovo war: A recapitulation. International Affairs, Vol 85, No 3 p. 447-459. https://doi.org/10.1111/j.1468-2346.2009.00807.x

29. Wright, S.C. Taylor, D.M. and McArthur, J. (2000). Subtractive bilingualism and the survival of the Inuit language: Heritage-versus second-language education. Journal of Educational Psychology, Vol 92, p. 63-84. https://doi.org/10.1037/0022-0663.92.1.63

30. Yoel, J. (2020). The visibility of the English language in the linguistic landscape of two teacher training colleges in Israel. Journal of English as an International Language, Vol 15, No 1 p. 44-63. Available at: https://files.eric.ed.gov/fulltext/EJ1259938.pdf 